Vol. 30, julho 2014, http://dx.doi.org/10.5380/dma.v30i0.33988

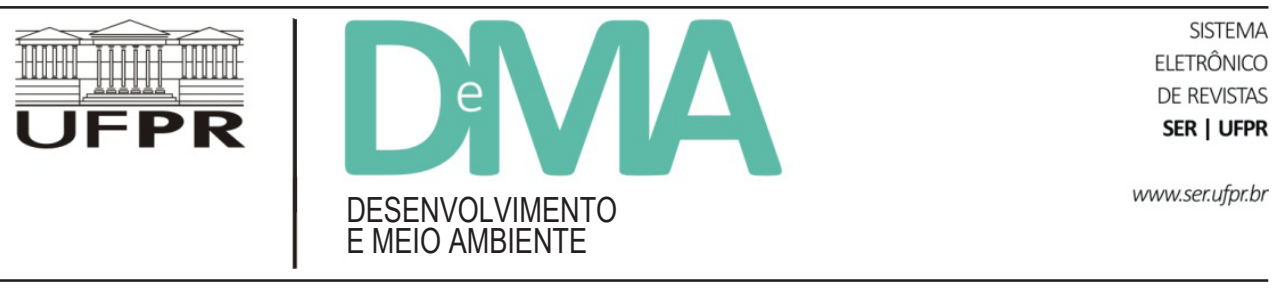

\title{
Assessing the Role of Socio-Ecological Learning in Participatory Governance: Building Resilience in Six Brazilian River Basin Committees
}

\section{Avaliando o papel da aprendizagem socioecológica em governança participativa: construindo resiliência em seis comitês de bacias hidrográficas brasileiras}

\author{
Anne BROWNING-AIKEN ${ }^{1}$, Márcio Claudio Cardoso da SILVA², José Antonio Silvestre FERNANDES NETO³, \\ Daniel da SILVA ${ }^{4}$ \\ ${ }^{1}$ Ph.D. in Anthropology (University of Arizona). Senior Researcher of Water Policy and Governance, Udall Center for Studies in Public Policy. \\ E-mail: browning@u.arizona.edu \\ ${ }^{2}$ Doutor em Engenharia Ambiental (UFSC). Instituto Federal de Educação, Ciência e Tecnologia de Santa Catarina (IFSC). E-mail: \\ mcardozzo@hotmail.com \\ ${ }^{3}$ Doutor em Engenharia Ambiental (UFSC). Analista de Gestão em Saúde. Fundação Oswaldo Cruz (FIOCRUZ). Email: fneto28@yahoo.com \\ ${ }^{4}$ Doutor em Engenharia de Produção (UFSC). Departamento de Engenharia Sanitária e Ambiental, da Universidade Federal de Santa Catarina \\ (UFSC). Email: daniel.silva@ufsc.br
}

Article: Received in: October 22 2013; Final version accepted in: April 182014.

ABSTRACT Brazil has embedded the socio-ecological learning process in the participatory management of river basin councils through its "sister laws" on water and the environment. GTHIDRO or, Grupo Transdisciplinar de Pesquisas em Governança da Água e do Território/Tecnologias Sociais para a Gestão da Água (TSGA), a transdisciplinary group of researchers at the Federal University of Santa Catarina, took these laws and developed new interpretations of socio-ecological learning. They incorporated an ethical component and a dynamic and complex program of participatory "cycles of learning" that brought committees and communities to a common understanding of socio-ecological processes, laws, and potential for collective action. Using resilience theory as a framework for understanding how to sustain and enhance adaptive capacity (Folke et al., 2002), this paper analyzes the processes of socio-ecological learning, including focus groups, physical dynamics that blend the conceptual with the physical, visioning, socio-ecological mapping, project planning and community celebrations through interviews, meeting notes, and written documents of the six case studies. The potential for socio-ecological learning as a tool for building the capacity of basin committees (Turvo, Ermo, Nova Veneza, Orleans e Braço do Norte in the southern part of the state, Urubici in the mountainous region, and Concordia in the middle eastern part) to plan and implement projects is substantiated as an important tool for building the resilience of the combined systems. The case studies indicate that their greatest achievement is the Strategic Planning Model for Sustainable Development, entitled PEDS, which diagrams how to improve the management core group's capacity to plan and implement projects of their own design, using strategies they have learned and networks they have established in their watershed and state. While the potential for conflict over water and 
energy between the various economic sectors is strong in Brazil and elsewhere, with the GTHIDRO model the potential for collaboration on resource issues becomes even stronger.

RESUMO O Brasil tem incorporado o processo de aprendizagem socioecológica na gestão participativa dos conselhos de bacias hidrográficas por meio de suas "leis-irmãs" sobre a água e o meio ambiente. GTHIDRO, ou Grupo Transdisciplinar de Pesquisas em Governança da Água e do Território/Tecnologias Sociais para a Gestão da Água (TSGA), um grupo transdisciplinar de pesquisadores da Universidade Federal de Santa Catarina, abordou essas leis e desenvolveu novas interpretações de aprendizagem socioecológica. Eles incorporaram um componente ético e um programa dinâmico e complexo dos "ciclos de aprendizagem" participativos que trouxeram as comissões e as comunidades a um entendimento comum sobre os processos socioecológicos, as leis e o potencial para a ação coletiva. Usando a teoria da resiliência como uma estrutura para a compreensão de como manter e melhorar a capacidade de adaptação (Folke et al., 2002), este artigo analisa os processos de aprendizagem socioecológica, incluindo grupos focais, a dinâmica física que mistura o conceitual com o físico, a visão de futuro, o mapeamento socioecológico, o planejamento de projetos e celebrações comunitárias por meio de entrevistas, notas de reuniões e documentos escritos dos seis estudos de caso. O potencial de aprendizagem socioecológica como ferramenta para a construção da capacidade dos comitês de bacias (Turvo, Ermo, Nova Veneza, Orleans e Braço do Norte, na parte sul do Estado, Urubici, na região montanhosa, e Concórdia, no centro-leste) para planejar e implementar projetos está fundamentado como uma ferramenta importante para a construção da resiliência dos sistemas combinados. Os estudos de caso indicam que a sua maior conquista é o Modelo de Planejamento Estratégico para o Desenvolvimento Sustentável, intitulado PEDS, que esquematiza a forma de melhorar a capacidade do núcleo do grupo de gestão para planejar e implementar projetos de sua própria concepção, o uso de estratégias que se aprenderam e as redes que se estabeleceram em sua bacia hidrográfica e em seu Estado. Enquanto o potencial de conflito sobre a água e energia entre os diversos setores econômicos é forte no Brasil e em outros lugares, com o modelo GTHIDRO o potencial para a colaboração em questões de recursos torna-se ainda mais forte.

Palavras-chave: aprendizagem social; sistema socioecológico; governança participativa.

\section{Introduction}

Brazil has embedded the socio-ecological learning process in the participatory management of river basin councils through its "sister laws" on water and the environment initiated since 1997. The Brazilian government has created a bundle of federal laws focused on water as a common or shared good and the social participation of stakeholders in their implementation: the National Laws of Sustainable Development, Environmental Education, Water Resources, Conservation Units, and City Statute, which together create an integrated vision of development of natural resources. The Brazilian reform contains the tenets of good governance with the creation of multiple, redundant, and polycentric scales of management, as well as the inclusion of hybrid mechanisms of governance that combine state, market, and community institutions and actors (Kumler \& Lemos, 2008; Lemos \& Agrawal, 2006; Ostrom, 2001, 2005). The new water management model focuses on the river basin committee composed of representatives from water user groups, government, and organized civil society, with participatory or "social" learning as a key method for implementing this water policy within the context of sustainable development. Planning through social learning, "above all, is a cognitive process which expands and transforms the consciousness [of participants] and makes possible the formation and qualification of participants" to understand the complexities of socio-ecological systems within the context of development (Palavizini, 2006, p. 155-156, my translation).

To understand how this bundle of laws can be applied to the problems of existing watersheds, we turn to the work of a transdisciplinary group of researchers called GTHIDRO or, Grupo Transdisciplinar de Pesquisas em Governança da Água e do Território at the Federal University of Santa Catarina (UFSC), who have allied with research and extension units of the Empresa de Pesquisa Agropecuária and Extensão Rural de Santa Catarina and the Empresa Brasileira de Pesquisa Agro- 
pecuária. Not only do these institutions have a history of working together, but they also have the same overall project goal of implementing the new National Water Policy and other laws regarding the role of social participation in resource governance and a sustainable use of natural resources, particularly in regard to the cultivation of rice, the production of pigs, basic rural sanitation, and preservation of the Guarani Aquifer. Individual case studies were located in the southern part of the state of Santa Catarina (Turvo, Ermo, Nova Veneza, Orleans e Braço do Norte), in the mountainous region (Urubici), and in the middle eastern part (Concórdia) (Fernandes Neto, Annex B).

This project is based on the fundamental idea that the governance of water should be supported by

- Combining academic and practical experiences with technology, and working with institutions to implement local projects related to water governance

- A pedagogic strategy aimed at empowering communities to achieve sustainable development of their water resources

This research group incorporates an ethical component and a dynamic and complex program of participatory "cycles of learning" that brings committees and communities to a common understanding of socio-ecological processes, laws, and potential for collective action (factual knowledge). By "socio-ecological learning" we are using the model proposed by Pahl-Wostl and Hare (2004) that "embeds social learning in the socio-ecologic system where the outcomes of the participatory management process are of a technical and relational nature," or, more simply "learning together to manage together" (Mostert \& Craps, 2003; Ridder et al., 2005). More specifically, we agree with Pahl-Wostl that processes of social learning should thus follow the following guidelines:

- Build up a shared problem perception in a group of actors, in particular when the problem is largely ill defined (this does not imply consensus building).

- Build trust as base for critical self-reflection, which implies recognition of individual mental frames and images and how they pertain to decision-making.
- Recognize mutual dependencies and interactions in the actor network.

- Reflect on assumptions about the dynamics and cause-effect relationships in the system to be managed.

- Reflect on subjective valuation schemes.

- Engage in collective decision and learning processes (this may include the development of new management strategies, and introduction of new formal and informal rules) (Pahl-Wostl, 2002, p. 400)

In addition, the research group makes distinctions between social learning processes and outcomes, and between individual and social learning. Social learning is much more than just public participation or pro-environmental behaviors. With Reed et al., they argue that to be considered "social learning", a process must:

(1) demonstrate that a change in understanding has taken place in the individuals involved; (2) demonstrate that this change goes beyond the individual and becomes situated within wider social units or communities of practice; and (3) occur through social interactions and processes between actors within a social network.

Reed et al. agree "that a clearer picture of what is meant by social learning could enhance our ability to critically evaluate outcomes and better understand the processes through which social learning occurs. In this way, it may be possible to better facilitate the desired outcomes of social learning processes" (2010).

As we will demonstrate, the research team and the committees together incorporated these elements in their planning and deliberations. In addition, they developed the river basin committees' capacity to value and respect each other as well as the natural environment in which they live through discussions about their historical and present experiences with land and water use and development and their worldviews of nature (social skills and cognition). Their goal is for the committee and the community to acquire a longer view of themselves in their environment and to shift from an over-riding goal of increased productive capacity to one of increasing adaptive capacity. 
We apply resilience theory - especially "the capacity to buffer change, learn and develop" - as a framework for understanding how to sustain and enhance adaptive capacity in a complex world of rapid transformations (Folke et al., 2002). We use this theory's emphasis on stimulating innovation and communication to build and maintain ecological resilience (Holling, 2001). Resilience theory is the basis for adaptive management, which embraces the uncertainty of complex resource systems (Holling, 1978). It recognizes that social systems can absorb impacts and cope with climate variability and change by reorganizing, changing and learning in response to imminent threats. In short, resilience can be considered "a process in which different aspects of social systems may be modified and strengthened to induce change" (James et al., 2010). We examine the capacity of the river basin committees to adapt to drivers such as political and climate change in the context of food security and potential hazards such as flooding. We analyze the processes of socio-ecological learning, including focus groups, physical dynamics that blend the conceptual with the physical, visioning, socio-ecological mapping, project planning and community celebrations, through interviews, meeting notes, dissertations and masters theses, and other written documents reporting the work of GTHIDRO on the TSGA projects. We determine if resilience of the river basins to the original drivers through social learning has increased through a community empowerment assessment tool completed by the research team, basin committee evaluations of projects during its development, and a post and ante spider web evaluation (Laverack, 2005) completed by the river basin committees. This paper substantiates the potential for socio-ecological learning as a tool for building the capacity of basin committees to plan and implement projects that support the resilience of the combined systems.

This paper is divided into seven sections. We begin with the 1) context and strategic reason for selecting the six Brazilian basin committees within the state of Santa Catarina. Second, we describe the 2) methodology used in this six basin study and the nature of the data sources. Next we explain the 3) conceptual model which GTHIDRO has developed in order to understand the procedural nature of social learning, which occurs throughout the development of the river basin committees.
4) Fourth, we present examples of the social learning process in six basins. Fifth, 5) we examine the results of the research group and the committee evaluations. 6) We evaluate the role of social learning as a resilience tool by comparing its use within the PEDS (Planejamento Estratégico do Desenvolvimento Sustentável or Strategic Planning for Sustainable Development) model (see methodology section below) to its use in other communities in Brazil, Europe and the U.S. 7) Finally, we discuss what can be learned from the results of our research and suggest which social learning strategies might be particularly applicable elsewhere in communities facing water or energy crises.

\section{Geographic context}

The state of Santa Catarina has a history of meteorological extremes from rains that result in floods and heavy run-off to dryness following the wet period. In addition to the loss of human lives, there are major economic losses since the state is the fifth largest food producer in Brazil (ham, chicken, apples, rice, mussels, and oysters). In 2004 alone, the state experienced wet weather-related damages amounting to more than 1 million reais or $\$ 602,000$ USD and dry-weather damages of \$ 213 million USD (Instituto de Planejamento e Economia or CEPA). Thus agricultural success is very dependent upon a good climate information system and good agricultural practices regarding water (Dossiês das Tecnologias, Versão Preliminar, 2007). In addition, approximately 22.7 per cent of the population has no water treatment for potable water, a figure higher than the national level (Dossiês das Tecnologias, Objetivo 3, 2007, p. 70).

TSGA focuses on the sub-hydrologic basins linked to the large Guarani Aquifer, which underlies parts of Argentina, Brazil, Paraguay and Uruguay (Figure 1).

A sub basin complex links the Rio Tubarão (towns of Orleans and Braço do Norte) to the Rio Araranguá (towns of Ermos, Turvo, Araranguà, among others.), Rio Tijucas (town of same name), Rio Canoas (town of Urubici), and Fragosos Basin (town of Concórdia) (Figure 2).

Generally speaking, the basins near the coast tend to have more rice cultivation, while the basins in the higher elevations are devoted to animal and agricultural farming. 


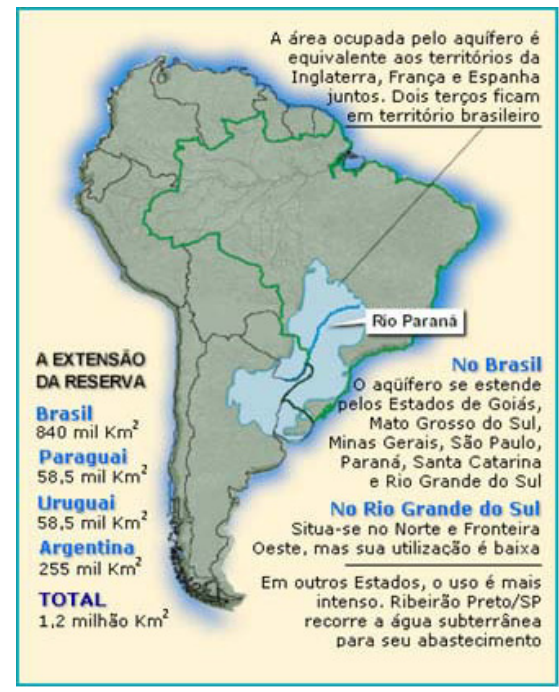

FIGURE 1 - Location of the Guarani Aquifer in South America, where it spans four countries Brazil, Argentina, Uruguay and Paraguay.

SOURCE: Da Silva, p. 120.

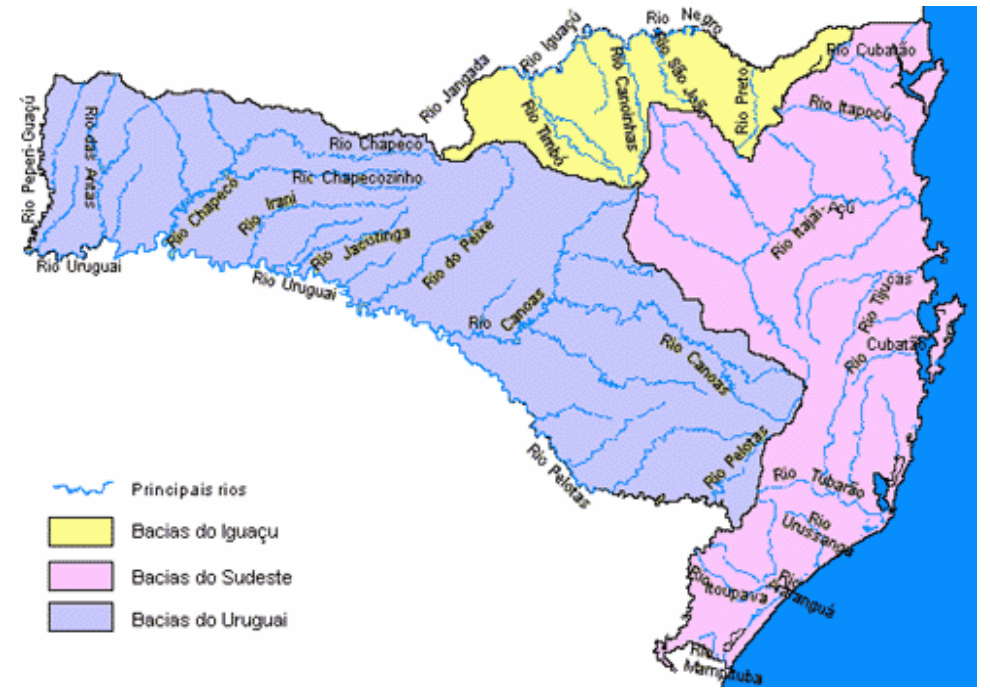

FIGURE 2 - River basins of Santa Catarina (Companhia Catarinense de Águas e Saneamento - CASAN, 2011).

\section{Methodology}

The social learning approach described in this paper originates from the enactment of the Brazilian National Water Resources Management Act of 1997, which included both water policy and an integrated water management system with tools or guidelines for designing water management plans. At the core of this policy and management system lies the explicit emphasis on stakeholder participation in this planning and management process. This paper reflects the experiences of the authors in developing an effective system of social participation in watershed governance through cycles of learning with existing or potential watershed councils, municipal, state and federal water and land use agencies, and with local schools. Information about these cycles of learning is thus based on their personal experiences with basin communities in planning and coordinating a series of projects focused on water quality issues and environmental conservation of watersheds. The data and materials were recorded in ten relatorios or reports from these projects, masters and Ph.D. theses written by UFSC students participating in the projects, and educa- tional materials developed for watershed committees and local schools.

The gradual development of a Strategic Planning Model for Sustainable Development, entitled PEDS (Figure 3), lays out the steps for getting diverse sectors of the population to work together, to understand what kinds of knowledge are required for watershed governance, to formulate a strategic watershed plan, and to evaluate and adapt the plan continuously.

We examine the effectiveness of this model in ter$\mathrm{ms}$ of the project's series of self-evaluation and in terms of other experiences in social learning for watershed governance in Brazil and elsewhere. This Strategic Planning Model for Sustainable Development was developed by GTHIDRO based on the constructivist method of Piaget and Paulo Freire and on the concept of love as the valorization of the subjective perspective of each person in a social group (Da Silva, 2008). Similar to the conceptual model developed by Pahl-Wostl and Hare (2004) this framework embeds the process of social learning in the context of governance structure and natural environment. It emphasizes that in the process of resource management, social involvement (e.g. the generation of 


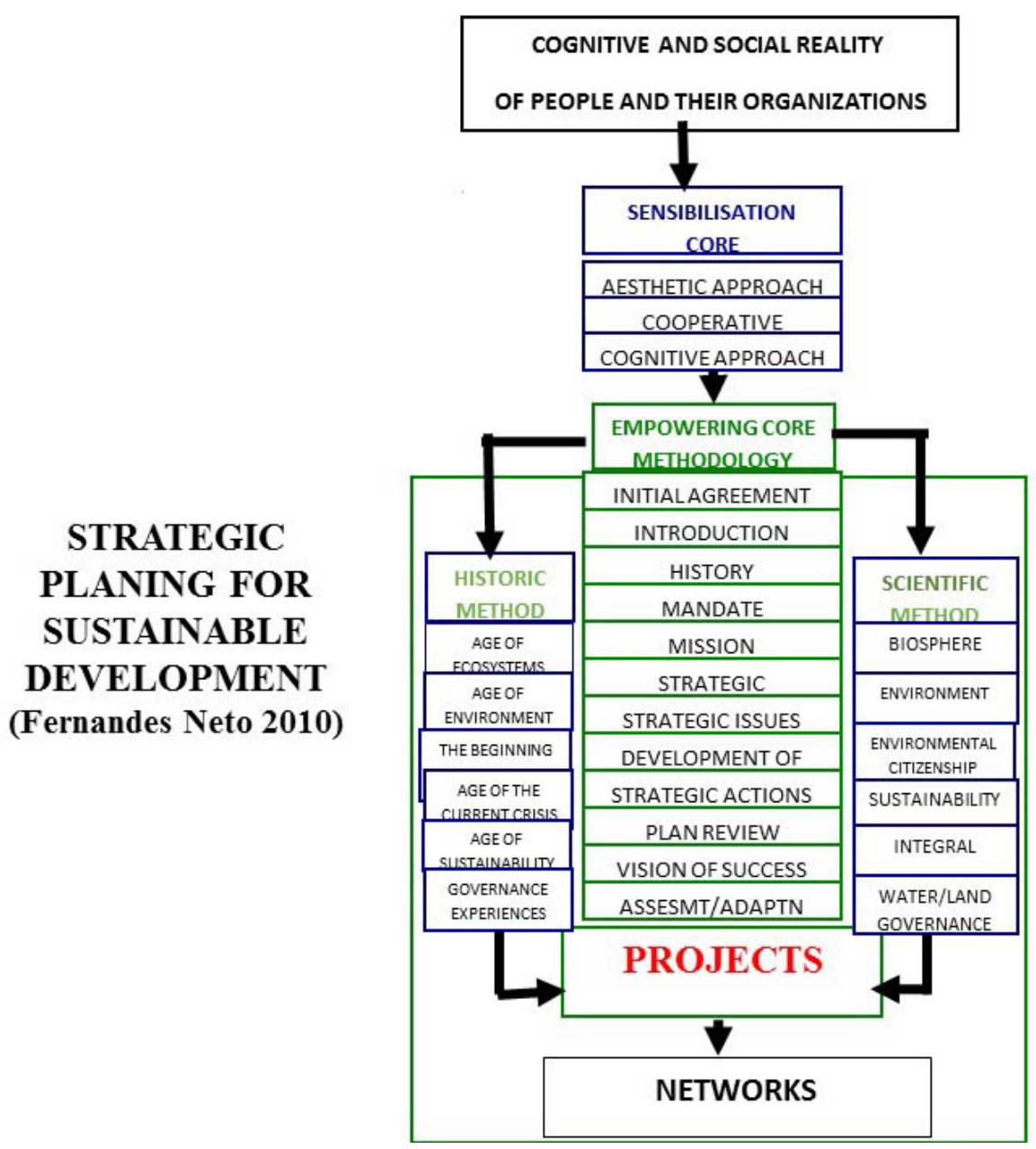

FIGURE 3 - Strategic Planning Model for Sustainable Development - PEDS.

social capital, the development of new social practices) is as important as content management (e.g. the development and communication of knowledge about the state of a water resource and the use of models to predict the effects of measures to achieve a good ecological state of a river). The outcomes of the management process are not only technical qualities such as an improved state of the environment but also relational qualities such as an improved capability of the actors to solve conflicts and come to cooperative agreements (Pahl-Wostl \& Hare,
2004, p. 194-195). Very simply expressed, a Community of basin representatives (Learners) creates a new form of Management based on their new and previous experiences and knowledge (see Figure 4).

Basin communities use the PEDS Model in a cumulative and reiterative process for establishing and evaluating the governance of a river basin. Social learning is a key part of this process, and takes several forms, as we will indicate in the following description of the model framework. With Pahl-Wostl et al. and 
Mostert et al., we point out that using social learning within this framework offers basin stakeholders a process for working together 1) to understand each other's value systems for water decision-making, 2) to develop trust, 3) to jointly define the nature of the problem they are trying to address, 4) to engage in fact-finding, 5) to develop and assess different strategies for addressing problems, and 6) to carry out a plan and assess its success in achieving their goals (Pahl-Wostl et al., 2007; Mostert et al., 2007). The entire model for Water Governance is premised on a triad of a community's previous experiences with resource or development projects, the willingness of the community participants to learn from each other and to understand and apply the science and laws necessary to carry out a project, and the ultimate goal of creating and implementing a local management plan for the natural resource.

\section{LOCAL MANAGEMINT}

\section{COMMUNITY OF} LEARNERS

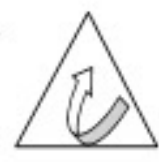

PRE VIOUS

EXPERIENCES
FIGURE 4 - Social learning in six river basin communities in Santa Catarina, Brazil.

Santo Amaro and Águas Mornas (Cubitão River Basin) Sensibilisation, Initial Agreement and Science Pedagogy in the schools: "Social Management of the Water in the Rio Cubitão-Sul, S.C., August 2010-June 2011"

This recent effort established an executive basin committee with the express purpose of constructing a basin management plan that would include three basic elements: an environmental education network throughout the schools, a system for managing hydrologic data, and a monitoring program for water quality. In order to arrive at an Agreement for doing this collaborative work, the group, led by a local coordinator and facilitated by Professor Daniel da Silva, explored the cognitive and social reality of each person and the organization they represented by using a dynamic in which everyone was asked to draw a flower in a vase and then to draw it again without looking at the actual object or first drawing. This demonstrated the fact that everyone came to the table with different concepts of what the environment could be visualized and interpreted. In addition, this exercise demonstrated how each individual had different skills in drawing or verbalizing his or her thoughts. These different perspectives and skills were to be valued and respected as part of their process of working together. The participants were further sensitized to the actual environment they were working in by going on a field trip to the basin to discuss the aesthetic dimension of the region, the water cycle in the basin (cognitive dimension), and the nature of cooperation required to address the issues the committee was interested in.

This step was followed with a series of meetings called "Spirit of the Laws", designed to help participants understand the nature of the environmental and water laws that supported their work through key word analysis and resynthesis of the laws in their own words as a group. It also enabled them to see that the laws empowered them to design and implement projects. This is part of the model's plan to construct a "community of learners," an essential ingredient to the concept of water governance.

In 2011, the Committee had begun to discuss the establishment of an environmental education network during a national conference on Social Management of Brazilian River Basins in the town of Santo Amaro. UFSC students, under the direction of Da Silva, had already been teaching basic concepts in the local schools such as ecology, biosphere, the water cycle, the history of environmental degradation, and environmental stewardship with the cooperation of science teachers. Each of these classes focused on several dynamic or concrete ways to physically, conceptually and emotionally conceptualize the concept. For example, the concept of water scarcity was demonstrated by placing three gymnastic mats on the floor, representing bodies of water, and then playing musical chairs. Each time the music stopped, one of the mats was withdrawn so that more and more students ended up on one mat.

Concórdia (Jacutinga Basin): Establishing the cognitive and social reality of participants

In order to inventory the kinds of previous experiences with natural resource projects, determine what 
kinds of concepts were learned in those earlier processes and evaluate the strengths and weaknesses of those concepts, the UFSC Environmental Psychology Lab gave a questionnaire to 225 participants of the TSGA projects. This first step was used in June 2009 in the cities of Concórdia, Urubici, Turvo, Orleans and Braço do Norte, all in the state of Santa Catarina. Invited participants were selected from EPAGRI, educators from the elementary to the technical and superior levels, municipal health, security and agricultural offices, environmental police, city aldermen, rural agricultural producers, rural agricultural unions, professional associations, public school directors, members of rural agricultural cooperatives, and others considered to be important community representatives. Of the total 225,7 percent (15 participants) were from Concordia, and 40 per cent (91 participants) had taken the questionnaire for an earlier TSGA project in 2007. This group was used for a comparative study with those new participants (Relatorio 7, p. 43). The first part of this questionnaire asked participants to write 5 words or expressions that they associate with the word water. The words saúde (health), limpeza (cleanness or cleanliness), poluição (pollution), higiene (hygiene), indispensável (indispensable), nascente (source or spring), potabilidade (potability), alimento (food), qualidade (quality) and preservação (preservation) were repeated the most frequently (8 times or more) in all cities. Saúde was repeated with the greatest frequency (Relatorio parcial 7, p. 540).

The second question asked respondents to relate water to the concept of quality in 5 words or expressions. The testers interpreted the frequency of despoluida, limpa, incolor, potabilidade, and preservação to mean that the value of water was determined by its quality, which, in turn, was associated with its use and maintenance of health and life. Preservation of this resource was essential to maintain this use value. The third question asked for 5 associations with polluted water, and the words $\mathrm{mal}$, calamidade and alternativas occurred most frequently (Relatorio 7, p. 57).

A fourth question asked for 5 associations between water use and water exploration, with results suggesting that the words adequate, food, drink, knowledge, contamination, loss, building consciousness, economize, expenses, irrigation, necessity, and rational formed a word core (Relatorio 7, p. 65).

The configuration of the word choices were not the same for each city, but the results were brought back to the participants in a focus group for further discussion to identify what perspectives the group had about their own water, how they valued it, and what they saw were the challenges of maintaining basin water quality for their particular uses.

In Concordia, the results of the focus group led to the organization of a Field Day for Pig Raising and the Environment by the Regional Committee of the Suinoculture Association of the Upper Uruguay Basin Towns. Approximately one thousand participants rotated through exhibits where they received information about best practices for suinoculture (Relatorio 7, p. 23, Dia de Campo da Suinocultura e Meio Ambiente). Demonstrations for treating residues (biodigestores) from pig raising and reusing the residue for fertilizer and water for additional pigs were also constructed on private farms.

Braço do Norte (Tubarão Basin): Applying Environmental Education and Demonstration Sites to Suinoculture Pollution

Studies of Santa Catarina indicate the state has one of the highest indices of environmental pollution in Brazil, which represents an imbalance between economic development (7 percent of the national PIB) and natural resource use (water). One of the primary agricultural activities, pig raising, principally family farming with less than 50 hectares, generates with 5.7 thousand farm animals the amount of waste drainage or pollution equivalent to 25 million inhabitants. Close confinement of the animals, poor management practices, and lack of wastewater treatment have resulted in serious damage of the watershed (TSGA web site $<$ http://www.qualiagua. ens.ufsc.br/index.php?option $=$ com_content\&task $=$ vie w\&id=15\&Itemid=30 e vol2 $2 \mathrm{~J}>$ ). Other types of pollution, such as mining of sand and untreated domestic sewage, were also present (Comitê do Região Tubarão e Complexo Lagunar, v. $2 \mathrm{~g}$ ). In order to help the town of Braço do Norte address these problems and to form an Initial Agreement, in 2008 the TSGA team and the town designed a pilot project entitled Management of Residual Suinoculture Waste with a Focus on the Efficient and 
Integrated Use of Water. A key part of this project was the environmental education of the participants. Within ten months, 42 people, including the Brazilian Agricultural Research Corporation's (EMBRAPA), the Santa Catarina Information Center for Environmental Resources and Hidrometeorology, Farming and Animal Research, and Rural Extension Company of Santa Catarina (CIRAM - EPAGRI), rural producers, municipal officials and commercial leaders, students and professors from UFSC, environmental advocates and NGOs, were trained in the water laws, the relationship between different types of economic production and their impacts on the basin ecosystem, and technology for pig sanitation.

The group initially used a pedagogical tool, called "Three Moments" (a shortened version of the Cognitive and Social Reality Questionnaire): to establish the key water problems the community faced, to explore the nature of the problem, and to discuss the activities necessary to address these problems (Relatorio 2) along with thematic maps showing landscape changes over time. During this time pilot projects were also established as demonstration spots within private farms. One of these demonstration plots included the storage and treatment of pig waste on the farm of Sr. Valdir Wiggers (Relatorio 2, p. 30). At this demonstration site the sewage residue from pig production was first sent to a decantation pond with aeration to remove solids and sediments.

The next step was the biodigestor or a pond for treatment with an aquatic plant (lemnas aquaticas or duckweed) to remove bacteria, and finally sent to a holding pond from which the treated material could be pumped and combined with compost for fertilized irrigation (Dossiê de Tecnologias). The biogas produced consisted of an average concentration of $70 \%$ methane and $30 \% \mathrm{CO} 2$ which was converted to electricity and used to run small heaters in the winter (Rel 2:30). The group of 42 people from Braço do Norte became a community of learners with the TSGA team by helping to construct the materials at the demonstration site.

The idea of producing thematic maps emerged as a result of the town's initial Agreement and the participants' discussions about the nature of their earlier experiences with development projects. The TSGI team offered to teach the group how to read different kinds of maps and use the geographic information systems
(GIS) ARCExplorer, Spring and Google Earth. First the Urubici group learned how to collect specific data about soil types, vegetation cover, geohydrology, landscape land marks, etc., and to organize them into data banks. Much of the data was available on-line in the form of satellite images or digitalized maps, but the group also divided itself into thematic groups to compare the maps with what they actually observed in the field at specific geographic coordinates. Then, with the help of the GIS, they created thematic maps on geology, hydrology, ecology, sanitation and permanent preservation areas (APPs). These themes were selected because the community realized the information was essential to any kind of watershed planning. In this sense creating thematic maps was a means of empowering the community. Next they constructed two maps of the water demand: one for sanitation purposes and the other for educational tourism.

The thematic groups also went into the town and surrounding area to match geographic locations with landmarks or evidence of the particular themes. They photographed the sites they visited so they could be linked with the maps' coordinates.

This geographic exercise came as a surprise to many participants, even after living in the area for many years. During the field trips participants were heard saying:

"For us it has always been like this. These mountains and rivers have always been here."

"Inever thought that Water Rock actually gave us water from the Guarani Aquifer!"

"Cathedral Rock is our natural patrimony, so we need to take care of it."

"In the old times, people would look at the Araucaria as a wood resource to be cut and sold."

"There's trash on the top of the mountain that's going to flow down the mountain to us!"

These observations led the group to recognize that the Araucaria trees should be preserved and that the community should encourage tourism as an economic venture.

When each thematic group presented their maps and photos, more townspeople appeared out of curiosity or interest. As the group discussed their findings, they 
began to discover links between the different themes and realize the complexity of the interactions between the socioeconomic dynamics and the ecosystem. They knew this kind of information was essential to establishing any kind of strategic planning. These presentations gained the group municipal support, represented by the elected prefect and the chief of police, as well as requests for membership from NGOs not previously involved in the group's work. The entire community was also convinced that they needed to construct a sustainable development plan that would include the construction of a conservation area around the recharge area and other waterfalls associated with the Guarani Aquifer, a water and sanitation plan, an educational program of environmental tourism, and a conservation plan for the preservation of the remaining araucarias. The community also realized that the resources in their area could be considered common goods for which they were all responsible. The products of their work can be seen in the tourist guide, a placard along with a farm house as part of the conservation area, and the two maps for tourism and water/sanitation.

Urubici (Canoas Basin): Evaluating a Community's Empowerment for Water Governance

Although evaluation is featured in the last part of the model, it is also used at the end of each project activity with four questions or requests: 1) what are the strong points of the activity? 2) What parts need improvement? 3) Are there further suggestions or recommendations? And 4) give one word that synthesizes this activity/experience. These are all recorded and used during the team's planning sessions prior to moving on to another activity or stage of the model. The final evaluation, made with the basin committee and other participants, occurs at the end of the project. The main purpose is to evaluate the group's sense of empowerment. The team defines "community empowerment" in terms of the group's increased ability to communicate ideas and values. In order for this to be a significant measurement, the evaluation also has to occur at the beginning of the project as well as during the Cognitive and Social Reality stage. At the conclusion of the project, each individual is asked to respond to nine dimensions of social empowerment as measured by Laverack (2005). The graphic below represents the compiled evaluations for the Urubici group, with whom TSGA had been working for ten years:

\section{Empowerment Evaluation for Urubici}

In addition to workshop evaluations, a broader schematic assessment was created and implemented, which required a baseline and final evaluation on six specific aspects of social learning within the community governance group. Because of the recent addition of this tool to the social learning model, out of all the basins, only Urubici actually used this method of assessment. Participation of the Urubici community was measured by the willingness of the participants, which included municipal officials and the Regional Council of Tourism, to break up into work groups in order to deal with the complexity of the issues they faced. It also refers to the level of discussions about the issues held during any meeting (Fernandes Neto, 2010, p. 182).

In Figure 5 the first arm of the web refers to participation, which reflects the constancy and the engagement of the participants in attending all the meetings. The second arm was leadership, which refers to the willingness of community leaders to recognize and deal with complex problems, rather than dismissing items as "externalities." Organizational structure refers to the degree of broad representation within the basin committee. This appears to be the Urubici group's strong point, even from the beginning.

Problematization of reality means to examine or question what appears to be reality. It is another way to recognize the complexity of watershed governance and to construct or acquire new knowledge about the nature of problems of resource governance. It also requires participants to question and consider whether an issue is either a cause or symptom of larger problems. This was particularly the case with learning about the new laws and about the nature of the area in and around Urubici.

The capacity to mobilize resources refers not only to funding for projects, but also to the ability to find and use knowledge sources, whether it is local or scientific knowledge. The segment was clearly a problem for the group, but they did make some improvements over the course of time.

The sixth arm, critical conscience, requires the group to coalesce from a series of interests to a group 


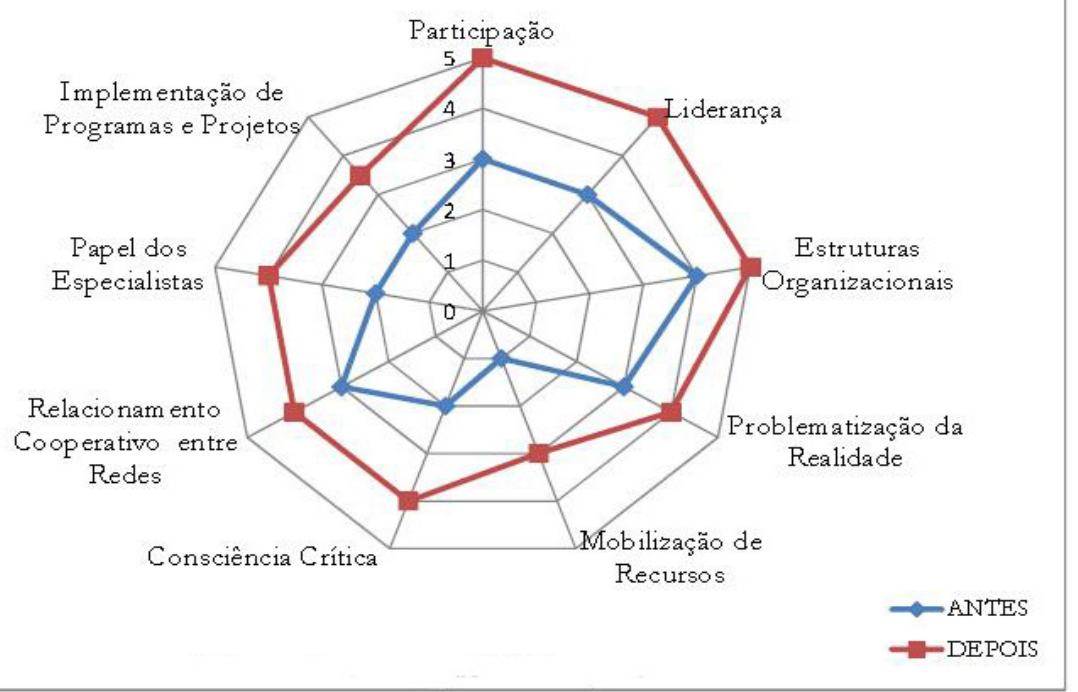

FIGURE 5 - Schematic assessment of basin empowerment success.

SOURCE: Fernandes Neto, 2010.

aware of the values and knowledge of other members of the group and to use this knowledge to find solutions to problems.

The cooperative relationship of the group with other parts of their network is an extension of the critical conscience. In the case of the Urubici group, this meant that the group stopped blaming municipal officials for not solving problems and began working with them as part of a community of learners. This arm showed positive change over time.

The eighth arm covered the role or use of specialists in the process of social learning, and the group showed about the same progress as the two preceding domains. The final domain covered the degree to which the group implemented projects and programs. This remained a challenge for the group because, despite their increased level of maturity and knowledge about resource governance, the group still did not think they could carry out all their projects. There was also some resistance from the larger community about the project to create an araucaria conservation area.

This before-and-after evaluation was presented to the group for discussion, and in a sense provided the group with additional social learning about themselves as a group. It also pointed the way for the group to move ahead and find solutions for adapting or implementing unfinished projects. Other projects were not yet ready for evaluation, so we have only this one example of the final part of the model, the final evaluation.

\section{Discussion}

This model for building a community's capacity for local resource governance through various forms of social learning pays far more attention to each process in the model and in the importance of each individual understanding the cumulative nature of the process, learning to work within the group, learning about hydrology, map making, laws, organizational and project design - subjects the individual may have had neither knowledge nor interest in until the group began to meet. The research group itself adjusted the model several times, as the diagrams from the masters and dissertation indicate over time. They too learned by experience to make the model work more smoothly and effectively. 
Perhaps the model's greatest achievement is its ability to improve the management core group's capacity to plan and implement projects of their own design, using strategies they have learned and networks they have established in their watershed and state. This capacity is the very key to success in any development project, for the team or any development agency cannot remain in the community forever. The community itself must be able to manage the resource, which may require several projects, as it was the case of Urubici. In addition, much of what is acquired during the social learning process carries over into other ventures and truly enhances a community's capacity to value its human capital and to create a management plan for now and the future.

The success of this model of governance is also due to the policy and legal support by the Brazilian government. The water, conservation, and municipal laws spell out exactly what is expected from each community, they establish guidelines for representation on a water committee, and they are integrated with each other so that there are no departmental policy conflicts. The federal and state governments also supply some funding, but they encourage the communities to collaborate with universities and companies that provide funding for the kind of research and outreach that TSGA does. In fact, research indicates that the social learning approach can help government perform its role more effectively (Klijn \& Koppenjan, 2000).

Finally, the success of social learning also depends upon the group having a good trained facilitator that knows how to organize meetings effectively and can get individuals to "own" the projects as if they invented them. A good facilitator is also required for potential conflicts, dominating personalities and eliciting creative thinking of each person within the group.

\section{References}

CASAN - Companhia Catarinense de Águas e Saneamento. Bacias Hidrográficas, 2011. Available in: <http://www.scribd. com/doc/57874890/Bacias-Hidrograficas-santa-catarina>. Viewed in: June 15, 2011.

\section{Conclusion}

Watershed collaboration literature points out how difficult it is to identify objective measures of social learning (Kumler \& Lemos, 2008; Mostert et al., 2008), especially since the configuration of issues, participants, policies and support is different in each case. However, reviewing the work of GTHIDRO with six water basin communities, where policy and legal support are the same, provides us with a sense of continuity in the use of a model for resource governance built specifically on social learning. While the potential for competition between economic sectors for the various uses of water and energy is always present (Priscoli \& Wolf 2014), Brazilian water laws and government have provided communities and university researchers in the state of Santa Catarina with support for cooperation and collaborative planning on water and energy issues. In fact, the concept of community empowerment pervades the PEDS social learning and planning model and is confirmed by workshop evaluations, Fernandes Neto's before and after spider web measurement, and by the enthusiasm of local water users for their work together.

Social learning is a process that is both time and resource intensive, but working with complex socioecological systems, this version of it has the advantage of being integrated and comprehensive (cf. Hooper et al., 1999, Margerum \& Whitall, 2004) as well as designed to address misunderstandings that reflect a lack of knowledge, a political bias, or a very self-serving narrow perspective. Creating resource governance requires a high learning curve, even change in both group and individual behavior. Social learning, if used constructively, can do just that.

Cash, D. W.; Clark, W. C.; Alcock, F.; Dickson, N. M.; Eckley, N.; Guston, D. H.; Jager, J.; Mitchell, R. B. Mitchell. Knowledge systems for sustainable development. Proceedings of the National Academy of Sciences, 100(14), 8086-8091, 2003. 
Da Silva, D. Educação Ambiental para a Proteção do Sistema Aquífero Guarani e Águas Subterrâneas na Zona de Recarga Direta no Estado de Santa Catarina/Brasil. Texto elaborado por Daniel Silva (sic) em 23 de julho 2005. Florianópolis, SC: GTHidro/ENS/CTC/UFSC.

Da Silva, D. J. Uma abordagem cognitiva ao planejamento estratégico do desenvolvimento sustentável. 240 p. Florianópolis, Tese (Doutorado) - Universidade Federal de Santa Catarina, 1998.

Da Silva, M. C. C. Uma contribuição à gestão de bacias hidrográficas a partir da investigação histórica do ambiente: estudo de caso: Bacia Hidrográfica do Rio Canoas/SC. 1 V. Florianópolis, Dissertação (Mestrado) - Programa de Pós-Graduação em Engenharia Ambiental, Universidade Federal de Santa Catarina, 2004.

Fernandes Neto, J. A. S. Modelo Urubici de governança da água e do território: uma tecnologia social a serviço do desenvolvimento sustentável local. Florianópolis, Thesis (Doctoral) - Universidade Federal de Santa Catarina, Brazil. 2010. Anexo.

Folke, C.; Carpenter, S.; Elmqvist, T.; Gunderson, L.; Holling, C. S.; Walker, B. Resilience \& sustainable development: building adaptive capacity in world of transformations. Ambio, 31(5), 437-440, 2002.

Hollings, C. S. (Ed.). Adaptive environmental assessment \& management. London: John Wiley Sons, 1978.

Understanding the complexity of economic, ecological and social systems. Ecosystems, 4, 390-405, 2001.

Hooper, B. P.; McDonald, G. T. Facilitating Integrated Resource and Environmental Management: Australian and Canadian Perspective. Journal of Environ., Plan. \& Manag., 42(5), 747, 1999.

James, E.; Burton, C.; Andreas, D.; Ramirez, I.; Laguna, D.; Martinez, N.; Diaz, R. Climate Change and Hazards: Building Local Resilience. White paper, 2010.

PASI - Institute for Climate Change and Hazards in the Americas, Panama City, Panama. June 14-25.

Klijn, E. H.; Koppenjan, J. F. M. Public management and policy networks: foundations of a network approach to governance. Public Management Review, 2, 135-158, 2000.

Kumler, L. M.; Lemos, M. C. Managing Waters of the Paraíba do Sul River Basin, Brazil: a Case Study in Institutional Change and Social Learning. Ecology and Society, 12(2), 22, 2008.
Laurance, W. F.; Perez-Salicrup, D. Rain Forest Fragmentation and the Structure of Amazonian Liana Communities. Ecology, 82(1), 105, 2001.

Laverack, G.; Wallerstein, N. Measuring community empowerment: a fresh look at organizational domains. Health Promotion International, 16, 179-185, 2001.

Margerum, R. D.; Whitall, D. The challenges and implications of collaborative management on a river basin scale. Journal of Environmental Planning \& Management, 47(3), 409-429, 2004.

Mostert, E.; Craps, M.; Pahl-Wostl, C. Social learning: the key to integrated water resources management? Water International, 33(3), 293-304, 2008.

Ostrom, E. Understanding Institutional Diversity. Princenton: Princeton University Press, 2005.

; Janssen, M. A. Beliefs, Multi-Level Governance, and Development. Conference Papers - American Political Science Association 39-41, Annual Meeting, Boston, MA, 2001.

Pahl-Wostl, C.; Hare, M. Processes of social learning in integrated resources management. J. Community Appl. Soc. Psychol., 14, 193-206, 2004.

; Tàbara, D.; Bouwen, R.; Craps, M.; Dewulf, A.; Mostert, E.; Ridder, D.; Taillieu, T. The importance of social learning and culture for sustainable water management. Ecological Economics, 64(3), 484-495, 2008.

Palvavazini, R. Gestão social transdisciplinar do ambiente: uma perspectiva aos processos de planejamento e gestão social no Brasil. Florianópolis, Dissertação (Mestrado) - Universidade Federal de Santa Catarina, 2008.

Priscoli, J. D.; Wolf, A. T. Managing and Transforming Water Conflicts. Cambridge: Cambridge University Press, 2010.

Projeto Tecnologias Sociais para a Gestão da Água 2007. Relatório Parcial 2. Available at: $<\mathrm{http} / / \mathrm{www}$.qualiagua.ens. ufsc.br/images/pdf/Relatorio_Parcial_02.pdf $>$. Viewed in: June 15, 2011.

Reed, M.; Evely, A. C.; Cundill, G.; Fazey, I.; Glass, J.; Laing, A.; Newig, J.; Parrish, B.; Press, C.; Raymond, C.; Stringer, L. C. What Is Social Learning? Ecology and Society, 15(4), 2010. Available at: $<$ http://learningforsustainability.net/social_learning>. Viewed in: June 15, 2011. 